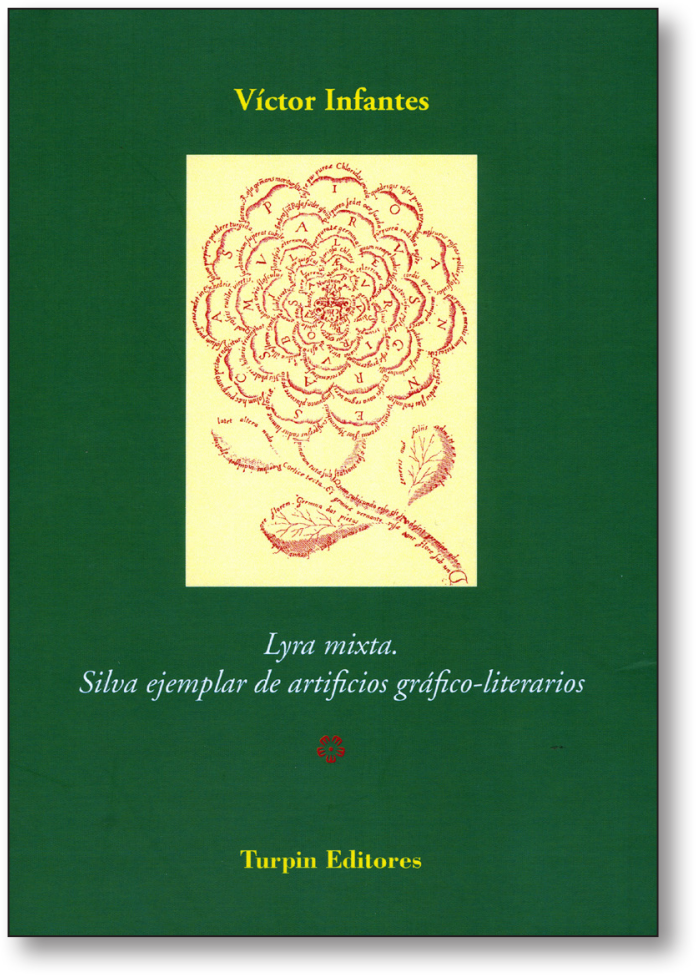

Tras una larga trayectoria investigadora, la producción intelectual suele quedar dispersa, y es por ello que una parada reflexiva para recapitular lo publicado se hace necesaria. No estamos aquí ante el único compendio de este tipo realizado por Víctor Infantes, caracterizado siempre por una clave temática que conforma el denominador común de los estudios reunidos en cada compendio, aspecto que resulta fundamental para entender el enfoque inherente. De esto nos han dado cuenta numerosos investigadores, de entre los que no puedo dejar de recordar a E.H. Gombrich, quien supo magistralmente cohesionar estudios dispersos confiriéndoles un alma particular, imprescindible para quienes posteriormente han pretendido abordar las entrañas de su pensamiento y su cultura humanística.

El presente libro de Víctor Infantes, bajo el título de Lyra mixta, constituye un sólido sumario que toma vida bajo la clave de la

\section{Lyra mixta. Silva ejemplar de artificios gráfico-literarios}

Victor Infantes

Madrid, Turpin Editores, 2015.

relación entre la palabra y la imagen, «pero que podría acogerse a otros muchos rótulos: la escritura de la imagen, la literatura gráfica, la representación del texto, el texto como figura, etc., que, en el fondo de su sentido, quieren expresar lo mismo», dice el texto de la contraportada. Continúa así: «Se aborda el universo icónico y textual de la emblemática, la cartografía de los acrósticos, laberintos, caligramas y demás formas gráfico-literarias de la poesía figurada; con multitud de reproducciones, donde el lector, también como espectador, puede asistir al espectáculo tipográfico de las más alambicadas formas de expresión poética experimental a lo largo de varios siglos». Se trata pues de un ejercicio que establece como eje argumental la relación del lector-espectador con la obra de modo directo y sin mediación, algo que substancialmente caracteriza la "recepción» literaria y lo diferencia de lo que en general -entiéndase así, y no como 
norma absoluta- podemos juzgar como «recepción» de la imagen por medio de las artes visuales: en donde habitualmente, en los siglos anteriores a la modernidad, se hace desde la participación mediata de un intérprete (instructor, predicador, maestro...). Es evidente que el consumo literario, como fenómeno no mediato, es algo muy diferente respecto del que corresponde a la mirada en el arte visual, aunque en cierto modo gran parte del público se comporte de un modo similar ante ambos fenómenos: lectura y visualización, algo que en realidad forma parte de la capacidad humana de aprehender desde la disposición misma del texto ilustrado, presente ya desde la Antigüedad. En este sentido Víctor Infantes, con razón, tras su experiencia observadora, afirma que «una gran parte del público lector del siglo XVI y XVII quizá no saboreaba más literatura que la comedia de moda, el pliego milagrero, aventurero o devoto, la novelita o el cuento de una Floresta y la sorpresa del ganador de una Justa que ensalzaba al patrón regional, o prolongaba en el recuerdo la nobleza y bondad del personaje desaparecido" (p. 64). A lo que podría añadirse que este mismo lector también «leía» las imágenes con idéntica mentalidad, puesto que la literatura que consumía ejercería por sí misma el papel de mediación visual.

Por el hecho de ir presentando los diferentes artículos de modo cronológico en cuanto su publicación, la lectura de este libro -al menos la mía, que ha pretendido la síntesis- inspira una sensación de autobiografía intelectual que probablemente el autor no ha querido. Me limitaré aquí solamente a tratar de aproximar un breve elenco -limitado a lo más importante-de lo reunido en este grueso volumen de casi 500 páginas, por cuidado de no hollar una vasta producción en el ámbito de la Historia de la cultura literaria, por parte un profano como quien suscribe, que se mueve con más seguridad en otra Historia complementaria a ésta, la de la cultura artístico-visual.
Se abre el libro con un primer artículo datado en 1980, con el título: "La textura del poema: disposición gráfica y voluntad creadora», que permite al autor ofrecer la definición de las diferentes tipologías, o géneros, clasificables dentro de estos principios de la llamada «literatura gráfica»: acrósticos y retrógrados dentro del primer grupo; el tipo mixto de las composiciones concordantes donde se combina una rima con concretas disposiciones tipográficas que revelan el artificio poético; un tercer grupo formado por la poesía «visual» propiamente dicha, conformada mediante laberintos, pentacrósticos figurados y caligramas; un cuarto grupo en el que el carácter visual no radica en el entramado poético, sino en la superposición de otros códigos, especialmente el gráfico, en donde cabe situar la emblemática en sus diferentes variantes. Por medio de estas claves, ofrece a continuación una aproximación a la poesía gráfica del polifacético Juan de Caramuel, y a reivindicar todos estos recursos del Barroco como preludio de la llamada "Poesía experimental» de las Vanguardias del siglo XX (1981). Con "Calderón y la literatura jeroglífica» (1983), entra en el ambiente de las celebraciones festivas del siglo XVII, con sus justas y premios, en donde se centra en el jeroglífico poético de Calderón, situado en la estela del Arte Poética de Juan Díaz Rengifo, el primero en plantear esta forma poética. Víctor Infantes reivindica una parte de la producción literaria de Calderón, modelo del género, que inadecuadamente ha sido incluida en las bibliografías como «Obra en prosa». El haberse ocupado de las Danzas de la muerte, obra conocida y capital del autor, explica que se incluyan trabajos como «Literatura e iconografía macabra en la España de los Siglos de Oro» (1987).

Uno de los estudios preferidos de quien suscribe estas líneas, lo conforma el artículo: "La presencia de una ausencia. La emblemática sin emblemas». Es algo personal y emocional, si se quiere, puesto que es el 
estudio mediante el que conocí al autor, con quien coincidí en A Coruña en el Congreso Internacional de la SEE, organizado en 1994 por Sagrario López -con actas publicadas en 1996. Eran los tiempos en que historiadores de la literatura y del arte coincidíamos en el mundo de la emblemática y comenzábamos a aunar las diferentes sensibilidades en el seno de la Sociedad Española de Emblemática, y es también un momento en el que el autor se introduce ya de lleno en la sensibilidad de los estudios sobre emblemática. En este, Víctor Infantes aboga por aquella producción emblemática en la que está ausente la pictura, conformada exclusivamente como un producto literario que, por cierto, no ignora la «imagen» ya que ésta en definitiva termina por asentarse en el nivel mental del entendimiento, a cuyo dominio concurre todo iconismo independientemente de su soporte sensorial.

Irá a continuación atendiendo también diversas conformaciones gráfico-literarias y verbo-visuales: «Poesía matemática. (Un cartel poético para el Rey)» (1996); "Símbolos de la imagen para leer. Emblemas» (1996); «José González estrada o las peripecias (biblio-gráfico)literarias de un poeta laberíntico». Sucesivamente irá tomando protagonismo la consideración de la emblemática. En este sentido, otro hito importante lo constituye un artículo del año 2000: «La primera traducción de Alciato en España: Hernando de Villa Real y su Emblema o scriptura de la Justicia (1546)", donde nos descubre una primera traducción (parcial) de Alciato, como un testimonio más de la «emblemática sin emblemas». Se trata de un estudio filológico sobre este texto en relación con sus fuentes, abordando también la figura de Hernando de Villa Real, e incorporando un apéndice con su traducción. Seguirán otros artículos dentro del ámbito emblemático, sin olvidar tampoco otras expresiones dentro de la literatura gráfica, entre ellos: «La excusa poética de la lámina (o una imagen no vale más que mil palabras).
La emblemática tardía de los Recuerdos a la vida mortal" (2002), "[Caligrama para Un cartel tipográfico del Siglo de Oro. Al águila misteriosa San Juan Evangelista (Madrid, Antonio Gonçález de Reyes, 1689)]" (2002), y destacándose: "La santidad tipográfica en la España del Siglo de Oro. Las honras poéticas a San Juan Evangelista, patrón de los impresores» (2005), así como el estudio de las Danzas de Muerte de Holbein, tratado como una obra emblemática: «Hans Holbein, las Danzas de la Muerte y los primeros libros de emblemas: ¿la imagen de un texto o el texto de una imagen?» (2007). En la recta más reciente, Víctor Infantes se preocupa sobre el origen del fenómeno emblemático, y a ello responde una aportación realizada en el VI Congreso de la SEE (Gandía, 2007), en donde el autor parece realizar una parada reflexiva para ordenar los principales elementos de su quehacer en el ámbito de la emblemática: «Promesa para una hipótesis muy provisional de la secuencia emblemática" (2009). Los últimos tiempos irán caracterizados por otros estudios en el mismo sentido, algunos de los cuales la revista IMAGo ha tenido la suerte de presentar, algo que sin duda contribuyó a asentar sus inicios y que continuarán aportando prestigio de ésta. 
